\title{
Note
}

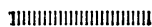

\section{Stimulating Effects of Inosine, Uridine and Glutamine on the Tissue Distribution of Radioactive D-Leucine in Tumor Bearing Mice}

\author{
Rensuke Goto, Atsushi Takeda, Osamu Tamemasa, \\ James E. ChaneY* and George A. Digenis* \\ Division of Radiobiochemistry and Radiopharmacology, Shizuoka College of Pharmacy \\ 2-1, Oshika 2-chome, Shizuoka-shi 422, Japan \\ * Division of Medicinal Chemistry and Pharmacognosy, College of Pharmacy, University of Kentucky \\ Lexington, Kentucky 40506, U.S.A. \\ Received September 16, 1983 \\ This experiment was carried out in search for stimulators of the in vivo uptake of $\mathrm{D}$-and \\ $\mathrm{L}$-leucine by tumor and pancreas for the possible application to $\gamma$-emitter labeled amino acids \\ in nuclear medical diagnosis. Inosine, uridine, and glutamine which are stimulators of the in \\ vitro incorporation of radioactive $\mathrm{L}$-amino acids into some tumor cells significantly enhanced \\ the uptake of D-leucine into the pancreas, while in Ehrlich solid tumor only a little if any in- \\ crease was observed. Of the compounds tested inosine showed the highest stimulation of pan- \\ creas uptake in the range of doses used, resulting in the best pancreas-to-liver concentration ratio, \\ a factor of significant consideration for pancreas imaging. The uptake of L-leucine by the \\ tumor and pancreas was little affected by these compounds.
}

Key Words: inosine, uridine, glutamine, tissue distribution, radioactive D-leucine, tumor bearing mice, pancreas imaging

\section{Introduction}

High radioactivity uptake of some radioactive D-amino acids by the tumor and pancreas of tumor-bearing animals ${ }^{1,2}$ ) or by the pancreas of normal mice ${ }^{3)}$ and rats $^{4)}$ has been reported suggesting the potential utility of $\gamma$-emitter labeled D-amino acids for the detection of tumor and pancreas. With regard to enhanced amino acid uptake, Gotto, et al. ${ }^{5)}$ and Belkhode, et al. ${ }^{6)}$ described the increased in vitro incorporation of the ${ }^{14} \mathrm{C}$-labeled amino acids $\mathrm{L}$-isoleucine, L-leu-

†担がん動物に扮ける放射性 D-ロイシンの組織内 分布に対するイノシン，ウリジン，グルタミンの 促進効果。五島廉輔, 武田厚司, 為政 脩, James E. Chaney*, George A. Digenis*: 静岡薬科大学放 射薬品学教室, 422 静岡市小鹿2-2-1, *ケンタッ キー大学薬学部, アメリカ合衆国ケンタッキー 州, レキシントン, 40506. cine, and L-alanine into Ehrlich or Krebs ascites carcinoma cells resulting from treatment with inosine, uridine, or glutamine. These findings suggest that these compounds might bring about the increased in vivo uptake of amino acids.

This paper deals with the in vivo effects of some nucleosides and glutamine on the radioactivity uptake of ${ }^{14} \mathrm{C}$-labeled $\mathrm{D}^{-}$and $\mathrm{L}$-leucine by the tumor and normal tissues of mice bearing Ehrlich solid tumor. The compounds tested were effective on the uptake of D-leucine by the pancreas, but only slightly enhanced the uptake of radioactivity from the leucine isomer by the tumor.

\section{Experimental}

2.1 Radioactive chemicals

$\mathrm{D}-\left[1{ }^{-14} \mathrm{C}\right]$-Leucine and $\mathrm{L}-\left[\mathrm{U}-{ }^{14} \mathrm{C}\right]$-leucine were products of ICN Pharmaceuticals, Inc., U.S.A. 
and Amersham International Ltd., U.K., respectively. The radiochemical purities were checked by paper chromatography before use.

\subsection{Tumor-bearing animals}

Ehrlich solid tumor-bearing mice were obtained by subcutaneous injection of $0.2 \mathrm{~m} l$ of Ehrlich ascites cell suspension $\left(10^{8} \mathrm{cells} / \mathrm{m} l\right.$ physiological saline) into the abdominal region of dd $Y$ strain mice $(16 \sim 18 \mathrm{~g}) 7$ days before use.

\subsection{In vivo uptake experiment}

A group of five tumor-bearing mice was intravenously injected with $0.2 \mathrm{~m} l$ of physiological saline containing radioactive $\mathrm{D}$ - or $\mathrm{L}$-leucine $(92.5$ $\left.\mathrm{kBq}(2.5 \mu \mathrm{Ci}) / \mathrm{m} l, 1 \times 10^{-3} M\right)$ and a test compound of varing doses. One hour later, the animals were sacrificed by exsanguination after being anesthetized by ether inhalation, and the tumor region and organs were excised from the mice. Preparation of the trichloroacetic acid (TCA)-soluble and -insoluble fractions from these tissues and the radioactivity measurement of the samples were performed according to methods described elsewhere. ${ }^{1)}$

\section{Results and Discussion}

\subsection{Effect of inosine}

Figure 1 shows the effect of inosine on radioactivity uptake by the tumor and organs of tumor-bearing mice after in jection of ${ }^{14} \mathrm{C}$-labeled D-leucine. Contrary to an expectation based on increased in vitro uptake ${ }^{5), 6)}$, the radioactivity uptake of the isomer in the tumor was slightly decreased by the administration of inosine. On the other hand, the pancreas radioactivity uptake from ${ }^{14} \mathrm{C}$-D-leucine was enhanced $40 \sim 75 \%$ by inosine treatment. This increase in radioactivity uptake was observed only in the TCA-soluble fraction (amino acid pool), whereas the uptake in the TCA-insoluble fraction (crude protein) was somewhat decreased. Inosine hardly affected the incorporation of L-leucine into either the TCA-soluble or -insoluble fractions of the pancreas. Belkhode, et al. ${ }^{6}$ reported that preliminary cleavage of inosine to ribose-1-phosphate appeared to be required for the stimulation of some L-amino acids, since the increased formation of ribose-1-phosphate might stimulate RNA syn-

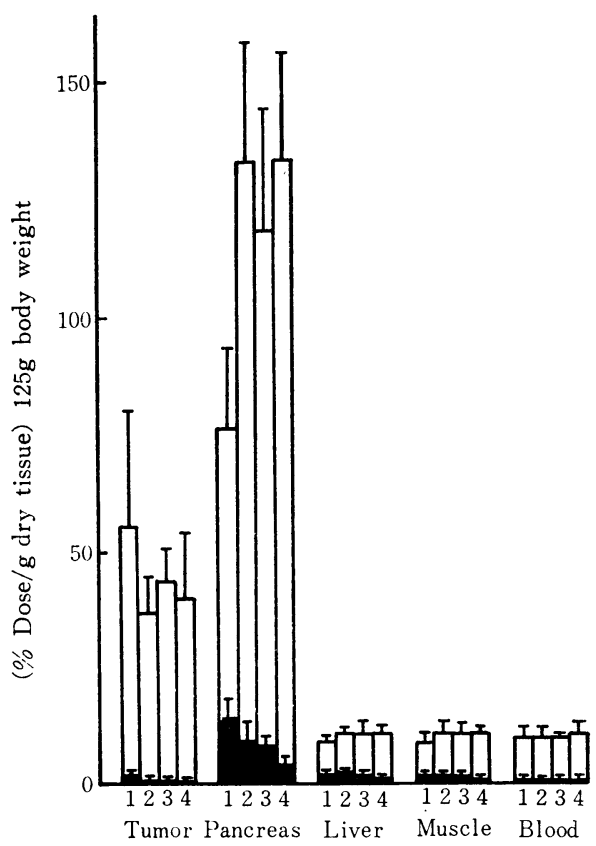

1: control, 2: inosine $(50 \mathrm{mg} / \mathrm{kg}), 3$ : inosine (100 mg/kg), 4: inosine $(200 \mathrm{mg} / \mathrm{kg})$

[: TCA-insoluble fraction, : TCA-soluble fraction

Fig. 1 Effect of inosine on radioactivity uptake by tumor and organs of mice bearing Ehrlich solid tumor after injection of ${ }^{14} \mathrm{C}$-labeled D-leucine.

thesis and ultimately protein synthesis. However, the result in this experiment indicates that inosine operates by influencing the transport of D-leucine rather than protein synthesis.

To test whether inosine metabolites or inosine itself plays a role in the above described increased membrane transport of $D$-leucine by the pancreas, inosine was intravenously injected two hours before administration of the radioactive amino acids. No difference between the co- and pre-administration of inosine on radioactivity uptake from $\mathrm{D}^{-}$or $\mathrm{L}$-leucine by the pancreas was observed, suggesting that inosine itself acts directly on uptake of $\mathrm{D}$-leucine.

\subsection{Effect of uridine}

Gotto, et al.5) showed that uridine gave slightly more stimulation of in vitro incorporation into Ehrlich ascites tumor cells than did inosine. In the present in vivo experiments, the radio- 


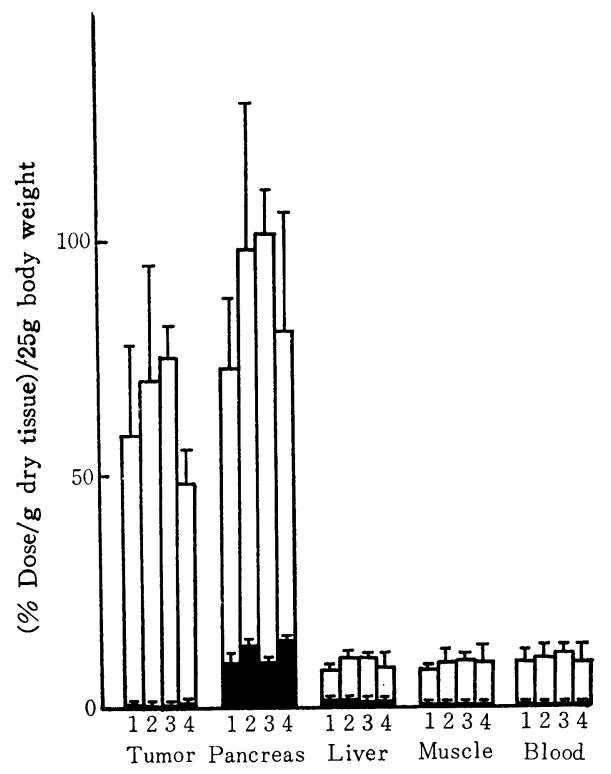

1: control, 2 : uridine $(50 \mathrm{mg} / \mathrm{kg}), 3$ : uridine $(100 \mathrm{mg} / \mathrm{kg}), 4:$ uridine $(200 \mathrm{mg} / \mathrm{kg})$

: TCA-insoluble fraction, : TCA-soluble fraction

Fig. 2 Effect of uridine on radioactivity uptake by tumor and organs of mice bearing Ehrlich solid tumor after injection of ${ }^{14}$ C-labeled D-leucine.

activity uptake from D-leucine into Ehrlich solid tumor was only slightly increased by uridine treatment at doses of 50 and $100 \mathrm{mg} / \mathrm{kg}$, but was inhibited at $200 \mathrm{mg} / \mathrm{kg}$ (Fig. 2). The trend observed for the relationship of pancreas uptake to uridine dose was similar to that observed for the tumor, but the degree of increased pancreas uptake was smaller than for that due to inosine administration. No enhancement of L-leucine uptake was observed for the pancreas.

\subsection{Effect of glutamine}

Herscovics and Johnstone ${ }^{7)}$, from a study of the stimulatory effects of glucose, uridine, and cytidine on the incorporation of ${ }^{14} \mathrm{C}$-formate into Ehrlich tumor cell protein in vitro, suggested that the increased intracellular concentration of glutamate in the presence of these agents leads to an increased availability of glutamine necessary for the synthesis of purine nucleotides and proteins. On the basis of this suggestion, the in vivo effect of glutamine on the uptake of $\mathrm{D}$ -

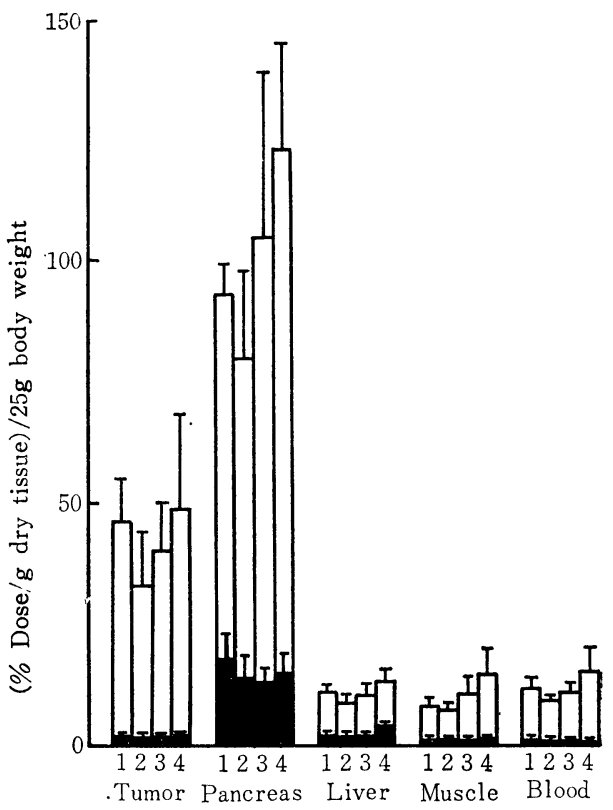

1: control, 2: glutamine $(23.4 \mathrm{mg} / \mathrm{kg})$,

3: glutamine $(117 \mathrm{mg} / \mathrm{kg}), 4$ : glutamine (234 $\mathrm{mg} / \mathrm{kg}$ )

D. TCA-insoluble fraction, TCA-soluble fraction

Fig. 3 Effect of glutamine on radioactivity uptake by tumor and organs of mice bearing Ehrlich solid tumor after injection of ${ }^{14} \mathrm{C}$-labeled $\mathrm{D}$-leucine.

and L-leucine was investigated. As shown in Fig. 3, the radioactivity uptake of $\mathrm{D}$-leucine by the pancreas increased about $30 \%$ at a glutamine dose of $234 \mathrm{mg} / \mathrm{kg}$, whereas no increase was seen for the tumor. Glutamine did not affect radioactivity uptake from ${ }^{14} \mathrm{C}$-L-leucine into any of the tissues studied.

Of the tissues examined, inosine, uridine and glutamine enhanced the radioactivity uptake of ${ }^{14} \mathrm{C}$ - $\mathrm{D}$-leucine into the pancreas only and did not alter ${ }^{14} \mathrm{C}$-L-leucine radioactivity uptake into any of the organs. We have already reported ${ }^{8) \sim 12)}$ that there are some differences in the membrane transport properties of $\mathrm{D}^{-}$and $\mathrm{L}$-leucine observed in in vitro experiments using Ehrlich ascites tumor cells; these differences include the binding of the isomers to the carrier membrane protein, the rate of efflux, the temperature dependence of transport, etc. Therefore, these differences in the uptake of the isomers by the pancreas 
Table 1 Effect of inosine, uridine and glutamine on pancreas-to-liver ratios of radioactivity uptake from ${ }^{14} \mathrm{C}$-D-leucine

\begin{tabular}{rcc}
\hline \multicolumn{1}{c}{ Inosine } & Uridine & Glutamine \\
\hline $8.28(0)$ & $8.32(0)$ & $8.56(0)$ \\
$11.73(50)$ & $8.60(50)$ & $9.49(23.4)$ \\
$10.15(100)$ & $8.86(100)$ & $9.87(117)$ \\
$11.71(200)$ & $9.81(200)$ & $9.20(234)$ \\
\hline
\end{tabular}

Numbers in parentheses show the doses $(\mathrm{mg} / \mathrm{kg})$ of the respective compounds.

after treatment with the stimulators is interesting and might be related to the mechanistic differences of $D^{-}$and $L$-amino acid membrane transport.

These stimulators may be useful in conjunction with D-leucine labeled with a $\gamma$-emitter (for example, ${ }^{11} \mathrm{C}$-labeled $\mathrm{D}$-leucine) in pancreas imaging which requires a high pancreas-to-liver ratio of the radioactivity uptake. As indicated in Table 1, the pancreas-to-liver ratio of radioactivity from ${ }^{14} \mathrm{C}$-D-leucine increased from 8.7 (control) to 11.7 in the tested dose levels of coadministered inosine, and only slightly in the presence of uridine and glutamine. Among these three compounds, inosine would be the best stimulator of D-leucine uptake, and it has a low level of toxicity $\left(L^{2} D_{50}=3 \mathrm{~g} / \mathrm{kg}\right)$. Methods involving diet manipulation and glucose-bicarbonate treatment has likewise resulted in increased pan- creas-to-liver ratios of radioactivity uptake from ${ }^{14} \mathrm{C}$-D-leucine and these findings will be the subject a further repor $\mathrm{t}^{13)}$.

The authors wish to thank Miss Mayumi Wada of laboratory (Shizuoka) for her technical assistance.

\section{References}

1) Tamemasa, O., et al.: Gann, 69, 517 (1978)

2) Tamemasa, O., et al.: ibid., 73, 147 (1982)

3) Goto, R., et al.: Chem. Pharm. Bull., 25, 1574 (1977)

4) Casey, D.L., et al.: Int. J. Appl. Radiat. Isotop., 32, 325 (1981)

5) Gotto, A.M., et al.: Biochim. Biophys. Acta, 80, 163 (1964)

6) Belkhode, M.L., et al.: Cancer Res., 27, 1073 (1967)

7) Herscovics, A. and Johnstone, R.M.: Biochim. Biophys. Acta, 91, 365 (1964)

8) Goto, R., et al.: J. Biochem., 86, 363(1979)

9) Goto, R. and Tamemasa, O.: Radioisotopes, 29, 1 (1980)

10) Goto, R., et al.: Chem. Pharm. Bull., 28, 1200 (1980)

11) Goto, R., et al.: ibid., 29, 1689 (1981)

12) Goto. R., et al.: J. Pharm. Dyn., 5, 780 (1982)

13) Goto, R., et al.: (Manuscript in preparation) 